\title{
Research on Ideological and Political Reform of Single Chip Microcomputer Course in Colleges and Universities
}

\author{
Yucun Wang ${ }^{1, *}$, Hongxiang Yang ${ }^{2}$

\begin{abstract}
${ }^{1}$ Shandong Agricultural University School of Information Science and Engineering, Tai'an City, Shandong Province, China

${ }^{2}$ Shandong Agricultural University School of Economics and Management. Tai'an City, Shandong Province, China

${ }^{*}$ Corresponding author.Email: wyc@sdau.edu.cn
\end{abstract}

\begin{abstract}
Curriculum ideology and politics is an educational mode that combines ideological education with classroom teaching. Single chip microcomputer principle course is an count for much course to those students of electronic information, electrical engineering, computer science and other science and engineering majors. The content of this course plays significant roles in cultivate students' engineering application ability, design ability, practice ability and other ability. Therefore, when teaching SCM course, teachers should make ways to combine the professional knowledge teaching of MCU with the ideological and political education of moral education, so that students can imperceptibly establish lofty feelings for the party and patriotism, and further strengthen the ideal and belief of students to strive for the prosperity of the country and nation Our country's high-end MCU professional and technical personnel is of great significance.
\end{abstract}

Keywords: Ideological and political course, Single chip microcomputer, Teacher, Course assessment.

\section{INTRODUCTION}

Curriculum ideological and political education refers to a kind of comprehensive education idea which takes "moral cultivation" as the fundamental task of education by constructing the pattern of all staff, whole course and whole course, which makes all kinds of courses and ideological and political theory courses go together in the same direction to form a synergistic effect. The main task of Ideological and political education is to combine the elements of Ideological and political education, including the theoretical knowledge, value concept and spiritual pursuit of Ideological and political education into each course, which has a subtle impact on students' ideology and behavior ${ }^{[1]}$. General Secretary Xi Jinping pointed out in his important speech at the National Conference on Ideological and Political Work in Colleges and Universities that the Ideological and Political work in Colleges and universities is related to the fundamental issue of cultivating what kind of people, how to train people and who to train for people in Colleges and universities. To run a socialist university with Chinese characteristics, we must strengthen the awareness of problems, adhere to the problem orientation, and build a firm ideological and political front ${ }^{[2]}$.

Single chip microcomputer is a small and perfect microcomputer system which uses VLSI technology to integrate CPU, ram, ROM, various I / O ports, interrupt system, timer / counter and other functions into a silicon chip. MCU is widely used in telecommunication, household appliances, industrial control, automotive electronics, instrumentation, medical equipment, aerospace, intelligent management and process control of special equipment. Single chip microcomputer principle course is an important professional basic course for electronic information, electrical engineering, computer science and other science and engineering majors. The content of this course is of great significance to cultivate students' engineering application ability, design ability, practice ability and innovation ability. Therefore, in the teaching process of SCM course, we must organically combine the professional knowledge teaching of SCM course with the political and ideological education of moral education, so that students can further strengthen their 
love for the party and patriotism while learning professional knowledge.

Due to the lack of understanding of ideological education, the importance of ideological and political education is not fully realized. In the teaching process of SCM course, there is the phenomenon of focusing on the impart of professional knowledge and ignoring the education of ideological value. Teachers often spend almost all their teaching time on the teaching of professional knowledge, but ignore the guidance of students' ideological education. Even if this kind of education can complete the imparting of professional knowledge well, it can not achieve the educational goal of cultivating students' all-round and healthy development. Therefore, it is necessary to reform the teaching method of SCM course, and allocate teaching time reasonably in the teaching process, which not only ensures the teaching of professional knowledge, but also realizes the all-round development of students. In fact, the application of single chip technology is very wide, so the single chip curriculum has a very rich material that can be introduced into the course of ideological and political teaching. This will not only help to enrich the content of the MCU course, but also help deepen students' understanding of the knowledge of the course.

\section{MEASURES TO STRENGTHEN IDEOLOGICAL AND POLITICAL EDUCATION IN THE COURSE OF SINGLE CHIP MICROCOMPUTER}

\subsection{Strengthen Teachers' Ideological and Political Understanding of Curriculum}

Teachers are the implementers of curriculum teaching. Only when teachers themselves have a high understanding of curriculum ideology and politics can they consciously complete the ideological education of students in the teaching process. Therefore, in order to be able to organically combine teaching and educating people as a whole in the course of MCU teaching, teachers should seriously learn to understand the guiding ideology of the new era of socialist education with Chinese characteristics, conscientiously implement the party's education policy. In the process of lesson preparation, teachers may wish to think more about the social significance behind the knowledge and the ideological value contained in the professional knowledge for the principle and application of professional knowledge. In this way, it can be targeted, and there will be a natural integration of ideological education in the teaching of specialized knowledge.

\subsection{Curriculum Content should Fully Reflect the Ideological and Political Elements of the Curriculum}

In order to cultivate talents with lofty ideals, the teachers of SCM course should fully explore the ideological and political elements contained in the course, and integrate them into all aspects of curriculum teaching reasonably, so as to realize the organic unity of Ideological and political education and professional knowledge education. In the past, the single-chip microcomputer course often only paid attention to the content of professional knowledge and professional skills, but lacked the appropriate content of Ideological and political courses. Although there still exist some gaps in the research and development of single chip microcomputer between China and the developed countries in the world, the development of domestic single-chip microcomputer is relatively slow, and there is a big gap with the mainstream single-chip manufacturers, but we should see that China has already made great progress in the research and development field of SCM. For example, China's Shanghai Neusoft carrier Microelectronics Co., Ltd., Hongjing Technology Co., Ltd., Shanghai Fudan Microelectronics Group Co., Ltd. have made good achievements in the field of MCU research and development. According to the latest chip data released by IDG earlier, from August to September of 2019, the MCU micro control unit of domestic chips has surpassed that of Korean enterprises, occupying the first place in the world in terms of sales volume ${ }^{[3]}$. In addition, in many application fields of single-chip microcomputer, China has also achieved fruitful application results, such as "the technical innovation caused by the single-chip microcomputer technology in the field of corrosion electrochemistry in China has filled the blank of corrosion online monitoring instruments at home and abroad"[4]. Therefore, in the teaching process of SCM course, we should introduce the relevant contents of the development of SCM in our country, which will help students to study professional knowledge and experience the spiritual wealth of the feelings of home and country, and help students establish the lofty ideal of fighting for the prosperity and strength of the country and the nation.

\subsection{Curriculum Assessment should Reflect the Content of Ideological and Political Education}

Course assessment is an important part of the teaching process in Colleges and universities. The results of course assessment are not only the stage conclusion of students' learning effect, but also the part basis of checking students' learning quality and teaching effect, so as to promote students' learning, summarize teaching experience, improve teaching methods and improve teaching quality. For the course of single chip microcomputer, although the main content of the course 
assessment is the professional knowledge and professional skills of the course, we should not ignore the assessment of Ideological and political content in the course assessment. Because the assessment of the course for students is a certain pressure, this pressure will become a kind of internal motivation for learning at ordinary times, and promote students to learn the corresponding knowledge more actively. Although we believe that the vast majority of students have enough enthusiasm and interest in learning, we should still retain certain incentive means to promote students' learning when necessary. Anyhow, course evaluation should abandon only evaluate professional knowledge and professional skill appraisal way, and the content of the course of ideological and political education should be incorporated into the curriculum evaluation. And this will be conducive to better carrying out the course of ideological and political work.

\subsection{The Guiding Ideology of Compiling the Teaching Material of Single Chip Microcomputer should Embody the Ideological And Political Education of the Course}

Textbooks are materials for teaching, such as textbooks, handouts, etc. All the materials that help learners to increase knowledge or develop skills can be called generalized teaching materials. Textbooks in a narrow sense are textbooks. Textbook is the core teaching material of a course ${ }^{[5]}$. As the concrete carrier of the curriculum content system, textbooks can regulate the teaching content of teachers on the one hand, and on the other hand, they are beneficial to students' curriculum learning. Therefore, in order to effectively carry out the ideological and political course, the textbook compilation of SCM course should carry out reasonable knowledge screening, and the textbook content should ensure that there is a reasonable ideological and political content of the course, so as to ensure that the curriculum transmits positive values.

\section{CONCLUSION}

General secretary $\mathrm{Xi}$ Jin-Ping stressed that we should adhere to the unity of explicit education and implicit education, and excavate the resources of Ideological and political education contained in other courses and teaching methods so as to achieve all-round and all-round education. As a course of teaching high-tech knowledge and training high-tech professionals, SCM course must actively respond to the call of General Secretary Xi, do not forget to educate people, organically combine ideological and political education with professional knowledge, and cultivate high-end talents with both professional skills and professional knowledge, as well as family feelings.

\section{AUTHORS' CONTRIBUTIONS}

Yucun Wang carried out the concepts literature search data acquisition and manuscript preparation. Hongxiang Yang provided assistance for data acquisition and manuscript editing.

\section{ACKNOWLEDGMENTS}

The authors thank the Library of Shandong Agricultural University for supporting this work. We also thank all the students who participated in the course survey for their constructive comments.

\section{REFERENCES}

[1] "baike.baidu.com", [Online]

Available:https://baike.baidu.com/item/\%E8\%AF\% BE\%E7\%A8\%8B\%E6\%80\%9D\%E6\%94\%BF/224 21661 ?fr=aladdin $(2020 / 12 / 20)$

[2] “theory.people.com.cn", [Online] Available: http://theory.people.com.cn/n1/2019/0104/(2020/12 /18)

[3] "xueqiu.com", [Online] Available: https://xueqiu.com/4927163759/133922702(2020/1 2/8)

[4] Xueyuan Zhang. Technical Innovation of Single Chip Computer in Chinese Electrochemical Corrosion Field. Journal of data Acquisition \& Processing[J]. VOL.13 Sup Oct.1998. P51-54.

[5] "hanyu.baidu.com", [Online] Available: https://hanyu.baidu.com/zici/(2020/12/16) 